PROCEDIA

Studi Kasus dan Intervensi Psikologi

ISSN:2302-1462

Volume 7(2) 65-73, Juli 2019

DOI: $10.22219 /$ procedia.v7i2.13024

\title{
Solution focused therapy untuk memperbaiki pola komunikasi ibu dan anak
}

Dini Cahyani, Universitas Muhammadiyah Malang, Malang, Indonesia

Korespondonesi:

Dini Cahyani, Universitas Muhammadiyah Malang, Malang, e-mail:dinichyani@gmail.com

Riwayat artikel
Naskah diterima:
04/04/2019
Revisi diterima:
20/05/2019
Naskah disetujui:
06/06/2019

\begin{abstract}
Abstrak
Subjek dalam kasus ini merupakan ibu dan anak yang memiliki permasalahan terkait dengan kualitas hubungan yang kurang baik yang ditandai dengan komunikasi yang salah. Asesmen yang dilakukan untuk penggalian masalah menggunakan wawancara, observasi, tes SSCT untuk anak dan kuesioner pola asuh untuk ibu dengan menggunakan PS-FFQ (Parenting style four factors questionnaire). Hasil asesmen menyebutkan bahwa mereka memiliki perbedaan pandangan dan adanya keinginan yang berbeda yang tidak tersampaikan dengan cara yang baik sehingga memperburuk pola komunikasi yang terjalin antara keduanya. Intervensi yang digunakan adalah solution focused therapy yang dilaksanakan dalam 6 sesi yang bertujuan untuk memperbaiki pola komunikasi antara ibu dan anak. Hasil intervensi yang diperoleh adalah ibu yang akan mengajak anaknya berbicara santai, bercanda, dan tidak akan marah-marah lagi dengan anaknya. Ibu juga memuji, memeluk, dan mencium anaknya setiap pagi. Anak juga memutuskan untuk bercerita tentang kegiatan kesehariannya di sekolah dan mulai untuk menyiapkan kebutuhannya sendiri dan mengikuti apa yang diperintahkan oleh ibunya tanpa mencoba untuk membantah.

Kata kunci: Solution Focused Therapy, pola komunikasi, keluarga, intervensi
\end{abstract}

\section{Latar Belakang}

Keluarga adalah unit utama di mana individu menemukan identitas diri dan keinginan mereka untuk hidup (Kumar \& Tiwari, 2008). Keluarga memainkan peran yang sangat signifikan dalam pengembangan kesehatan mental yang positif dan membuat seseorang memiliki sumber daya psikologis dan terorganisir secara social (Senthil, 2016). Keluarga memiliki pengaruh yang besar pada kepuasan hidup anggota keluarganya yang mencakup relasi pasangan, relasi orang 
tua dan anak serta relasi kakak dan adik. Interaksi dan komunikasi menjadi aspek penting dalam hubungan dan relasi dalam sebuah keluarga.

Dalam keluarga, konflik antara orang tua dan anak-anak tidak bisa dihindari pada semua tahap perkembangan. Konflik dapat terjadi akibat dari ketidaksepakatan tentang tugas-tugas rumah tangga. Konflik biasanya didefiniskan sebagai argument dan perdebatan sebagai perilaku orang tua dan anak yang saling menentang satu sama lain (Nelson, O'Brien, Grimm, \& Leerkes, 2014). Secara umum, komunikasi diantara anggota keluarga selalu dianggap sebagai aspek hubungan personal utama untuk mewujudkan dinamika hubungan keluarga. Pentingnya pola komunikasi dalam keluarga, membantu untuk menemukan peluang dalam mengekspresikan diri di kehidupan pribadi dan sosial (Zarnaghash, Zarnaghash, \& Zarnaghash, 2013).

Pola asuh orang tua juga berdampak pada hubungan komunikasi terhadap anaknya. Shahraki-sanavi, Baghbanian, \& Ansari-moghaddam, (2013) menjelaskan orang tua dengan pola asuh otoritatif akan mendorong komunikasi verbal dalam keluarganya dan sering kali memiliki hubungan yang ramah dan saling menghormati, bertanggung jawab serta mandiri. Orang tua dengan pola asuh otoriter dicirikan memiliki aturan ketat dan sedikit kehangatan karena memiliki standar pelaksanaan untuk mengendalikan perilaku anak. Orang tua dengan pola asuh permisif akan berperilaku secara lunak dalam menghadapi anak dan beranggapan bahwa memenuhi kebutuhan atau keinginan anak adalah cara menunjukkan kasih sayang dan cinta. Namun, orang tua seperti itu tidak dapat mendukung kebutuhan anak-anak mereka, dan menganggap penafsiran yang keliru dari tanggung jawab mereka sendiri. Seringkali peraturan dan sikap disiplin dominan dalam keluarga semacam ini. Anggota keluarga tidak cukup dihargai satu sama lain dan hubungan di antara mereka relatif tidak sehat, menunjukkan tingkat gangguan atau komunikasi mekanis.

Masalah yang terjadi pada kasus ini adalah adanya pola komunikasi yang salah antara ibu dan anak. Hal ini ditunjukkan dengan ibu dan anak yang sering terlibat pertengkaran, ketidaksepakatan dan pertentangan diantara keduanya Sikap ibu yang keras sering membentak, memarahi, mencubit, mendorong kepala anaknya yang memicu pertengkaran antara dirinya dan anaknya yang menyebabkan anaknya malas untuk berbicara dan berinteraksi dengan ibunya. Anak beberapa kali memutuskan untuk mengabaikan ibunya. Terbentuknya masalah antara ibu dan anak ini karena simtom yang dimunculkan oleh anggota keluarga akibat dari hubungan keluarga di masa lalu atau generasi sebelumnya yaitu pola didikan ibu sewaktu kecil yang diterapkannya kembali pada anaknya sehingga pertengkaran dan pertentangan antara ibu dan anak menyebabkan masalah komunikasi.

Salah satu intervensi yang dapat digunakan untuk menangani kasus tersebut adalah solution focused therapy (SFT). SFT merupakan salah satu terapi yang dikembangkan untuk mengidentifikasi masalah komunikasi dan interaksi anggota keluarga (Carr, 2006). SFT berfokus pada bagaimana memahami penyebab suatu masalah, memahami pola dalam masalah yang terjadi sehingga menemukan solusi atas permasalahan yang dialami (Ratner, George, \& Iveson, 2012).

\section{Metode Asesmen}

Metode asesmen yang digunakan dalam kasus ini adalah 1. Wawancara klinis yaitu dilakukan guna mengumpulkan informasi secara mendalam kepada anggota keluarga mengenai dinamika permasalahan yang terjadi, 2. Observasi guna mengetahui bagaimana pola komunikasi dan interaksi antar anggota keluarga, 3. Tes SSCT digunakan untuk mengungkapkan fungsi hubungan antara anak dengan kleuarga, lingkungan sekitar terhadap diri pribadi, 4. Kuesioner pola asuh digunakan untuk melihat pola asuh yang diterapkan oleh orang tua kepada anak. Kuesioner yang digunakan adalah PS-FFQ (Parenting style four factors questionnaire). Skala ini memiliki item sejumlah 32. Semua item memiliki validitas tinggi. Konsistensi internal 
diperkirakan dengan menggunakan alpha Cronbach. Nilai alpha 0,70 atau lebih dianggap sebagai kriteria untuk menunjukkan konsistensi internal yang kuat. nilai alpha 0,60 atau di atas dianggap signifikan. Disini realibilitas skala PSFFQ adalah 0,92 (Y, 2017).

\section{Presentasi Kasus}

Keluarga ini terdiri dari 3 orang yaitu, suami, istri dan 1 orang anak. Dalam kasus ini keluarga yang menjadi Subjek dalam terapi adalah dua orang anggota keluarga yaitu ibu (W) dan anak perempuan (D). D merupakan anak perempuan yang duduk di bangku kelas V sekolah dasar. D merupakan anak tunggal.

Hasil asesmen menunjukkan bahwa anggota keluarga tersebut mengalami masalah pada pola komunikasi antara ibu dan anak. Masalah yang terjadi pada keluarga ini yaitu ibu yang sering memarahi dan mengkritik anak dengan amarah yang meledak. ibu ingin anaknya mengikuti instruksi atau apapun yang dikatakannya karena ibu beranggapan bahwa dalam waktu-waktu tertentu dirinya berwenang memutuskan apa yang boleh dan tidak boleh dilakukan oleh anaknya.

Ibu menilai, di usia anaknya yang sudah memasuki angka 10 tahun, D merupakan anak yang manja dan tidak mandiri. Ibu W ingin anaknya seperti dirinya ketika berusia 10 tahun dulu dimana dirinya sudah mandiri dan bertanggungjawab atas kebutuhan dan kedisiplinannya. Ibu W mengakui bahwa dulu dirinya dididik keras oleh ayahnya. Namun, didikan keras tersebut membuat dirinya menjadi tidak dekat dengan ayahnya malah merasa seperti orang asing jika berada di dekat ayahnya dulu. Karena pengalamannya sewaktu kecil, ibu W sebenarnya tidak ingin mendidik anaknya seperti apa yang telah dilakukan oleh ayahnya. Maka dari itu ibu W ingin memperlakukan anaknya seperti temannya. Namun, pada beberapa keadaan ibu W juga ingin anaknya mandiri, disiplin, dan hormat padanya.

Dari hasil skala pola asuh yang diberikan pada ibu W, disini dirinya menerapkan pola asuh permisif. Pola asuh yang permisif mengungkapkan pendekatan yang terlalu toleran untuk sosialisasi dengan perilaku pengasuhan yang responsif dan tidak menuntut (Bibi, Chaudhry, Awan, \& Tariq, 2013). Ibu W merasa bahwa dirinya mungkin memiliki kesalahan dalam pola asuh sehingga anaknya tidak bisa menjadi mandiri. Ibu $\mathrm{W}$ sudah melakukan berbagai cara agar membuat anaknya mandiri bahkan sampai kesal dan marah-marah dan setiap hari harus memandu anaknya terkait dengan apa saja yang harus dikerjakan oleh D. Sunarty \& Dirawan (2015) menjelaskan bahwa ketika orang tua menerapkan pola asuh permisif untuk kemandirian anak maka komunikasi, interaksi orang tua dengan anak, baik dari kata-kata dan tindakan selalu memberikan kebebasan kepada anak-anak sehingga anak memiliki tanggung jawab yang kurang, kelalaian, sangat lemah dalam menerapkan sikap disiplin, dan kurang tegas dalam menerapkan peraturan. Hal tersebut juga dapat membuat kepribadian anak tidak tumbuh dengan baik dan termasuk menghambat kemandirian anak (Sunarty \& Dirawan, 2015).

Ibu W yang dulunya mendapatkan pola asuh otoriter dari ayahnya sebisa mungkin untuk tidak menerapkan hal tersebut pada anaknya. Akan tetapi ibu tidak dapat mengontrol amarahnya ketika anaknya tidak bisa mengurus kebutuhannya sendiri dan selalu dipandu terlebih dahulu. Kemarahan dan bentakan ibu membuat anak juga tidak jarang membentak ibunya juga. Ibu dan anak sangat jarang terlibat dalam percakapan hangat atau bahkan candaan. Ibu juga tidak pernah memuji, mencium ataupun memeluk anaknya. Hal tersebut dilakukannya karena ibu W merasa itu adalah perlakuan asing dan dirinya dulu tidak pernah diajarkan oleh orang tuanya untuk terlibat dan melakukan sentuhan secara emosional seperti itu.

Ibu W tidak dapat berperilaku luwes, santai, dan berpandangan terbuka pada anaknya karena pola asuh yang sangat disiplin yang didapatkan dari orang tuanya. Ibu W dibesarkan oleh orang tua yang keras dan disiplin. Sikap keras ibu terhadap anaknya merupakan bentukan dari didikan orang tua ibu $\mathrm{W}$ terdahulu. Ibu ingin anaknya menghormatinya sebagai orang 
tua dan mengikuti instruksi dan keinginanannya. Muraru \& Turliuc (2012) menjelaskan bahwa pengalaman utama dari keluarga asal memiliki dampak pada perkembangan individu dimana ketika individu memiliki keluarga baru dan membuat pilihan sendiri akan tetap terhubung secaea emosional dengan sistem hubungan keluarga asal.

Dari hasil SSCT, pandangan anak mengenai ibunya adalah seseorang yang suka marah-marah dan membentak. D sangat tidak suka untuk dibentak apalagi dicubit dan kepalanya di dorong. anak merasa bahwa ibunya tidak harus marah-marah pada hal yang tidak penting. Karena perlakuan ibu terhadapnya, anak ini sering membantah dan berteriak pada ibunya. D merasa bahwa tidak ada yang salah ketika ia bertanya hal-hal yang tidak diketahuinya pada ibunya akan tetapi respon ibunya malah marah-marah dan membentak dirinya. D sangat sakit hati dengan perilaku ibunya seperti itu karena bentakan dan pukulan merupakan kelemahannya, D mengaku itu adalah hal yang dibencinya. Karena perlakuan yang didapatkannya seperti itu, D lebih sering bercerita dan bercanda dengan ayahnya dan mengabaikan keberadaan ibunya. D juga memiliki pandangan bahwa hal yang tidak disukainya dari wanita adalah jahat. Menurut $\mathrm{D}$ wanita yang jahat adalah wanita yang sering membentak dan marah-marah terhadap orang lain seperti yang dilakukan oleh ibunya kepadanya.

Ibu menyadari bahwa dirinya memiliki interaksi dan komunikasi yang sangat minim dengan anaknya. Ibu merasa dia dan anaknya terlalu sering bertengkar bahkan komunikasi yang mereka jalin terkesan buruk, dimana anak akan berbicara dengannya ketika menyahuti kemarahan dan bentakkan darinya yang membuat keduanya lebih sering bertengkar. Mina Zarnaghash (2011) menjelaskan bahwa aspek paling dasar dari komunikasi keluarga adalah situasi percakapan dan dialog. Aspek kunci lain dari komunikasi keluarga adalah situasi kesesuaian yang mengacu pada sejauh mana komunikasi keluarga berfokus pada kesamaan kepercayaan dan sikap dalam interaksi sehingga interaksi yang terjadi berorientasi pada konformitas, menghindari konflik, dan perasaan saling bergantung dan lekat antar anggota keluarga (Fitzpatrick, 2004).

Pada kasus ini pola interaksi ibu dan anak ditandai oleh konflik dan sensitivitas antara keduanya. Hal ini ditunjukkan dengan ibu dan anak yang sering terlibat pertengkaran, ketidaksepakatan dan pertentangan diantara keduanya. Dinamika terbentuknya masalah dapat dijelaskan melalui teori family of origin yaitu simtom yang dimunculkan oleh anggota keluarga akibat dari hubungan keluarga di masa lalu atau generasi sebelumnya yaitu pola didikan ibu sewaktu kecil yang diterapkannya kembali pada anaknya. Pertengkaran dan pertentangan antara ibu dan anak menyebabkan masalah komunikasi. Ibu yang selalu marah-marah dan membentak sedangkan anak mengabaikan keberadaan ibunya, menyahuti dan membentak ibu dan juga anak malas untuk berbicara dengan ibunya.

\section{Diagnosis dan Prognosis}

\section{Diagnosis}

Berdasarkan uraiaan kasus, hasil asesmen dan rujukan yang ada di Diagnostic and Statistical Manual of Mental Disorder Fifth Edition (DSM-V) maka dapat ditegakan diagnosis V61.20 (Z62.820) bahwa permasalahan Subjek memenuhi kriteria diagnostic gaya interaksi dan komunikasi yang salah akibat pola asuh orang tua yang menekan anak dibeberapa keadaan sehingga menyebabkan pertengkaran, ketidaksepakatan dan pertentangan diantara keduanya.

\section{Prognosis}

Terapis memperkirakan keberhasilan intervensi untuk keluarga ini adalah positive/ baik. W dan D memiliki keinginan dan usaha untuk berubah dan memamahi intruksi yang diberikan terapis. W dan D kooperatif, meskipun ketika keduanya dihadapkan dalam satu tempat yang sama sedikit terjadi saling membantah 


\section{Intervensi}

Intervensi yang digunakan untuk menangani kasus ini adalah Solution focused therapy (SFT). SFT merupakan salah satu terapi yang dikembangkan untuk mengidentifikasi masalah komunikasi dan interaksi anggota keluarga (Carr, 2006). SFT merupakan terapi yang berfokus pada bagaimana memahami sebuah penyebab suatu masalah, memahami pola dalam masalah yang terjadi sehingga menemukan solusi atas permasalahan yang dialami (Ratner et al., 2012). Pendekatan pada SFT dapat memungkinkan seseorang untuk membangun sebuah perubahan dimasa depan atau yang akan datang (Ratner et al., 2012).

Lutz (2014) menjelaskan prinsip dari SFT, yaitu (1) didasarkan pada pembangunan solusi daripada pemecahan masalah; (2) Fokus terapeutik adalah pada masa depan yang diinginkan Subjek daripada pada masalah masa lalu atau konflik saat ini; (3) Subjek didorong untuk meningkatkan frekuensi perilaku bermanfaat saat ini; (4) Tidak ada masalah terjadi sepanjang waktu. Ada beberapa pengecualian; yaitu, ada kalanya masalah bisa terjadi tetapi ada kalanya tidak. Pengecualian ini dapat digunakan oleh Subjek dan terapis untuk membangun solusi; (5) Terapis membantu Subjek menemukan alternatif untuk pola perilaku, kognisi, dan interaksi yang tidak diinginkan saat ini dalam repertoar Subjek atau dapat dibangun oleh terapis dan Subjek; (6) Berbeda dari pengembangan keterampilan dan intervensi perilaku, model ini mengasumsikan bahwa solusi sudah ada untuk Subjek dan dapat ditemukan dengan percakapan antara terapis dan Subjek; (7) Peningkatan perubahan kecil menyebabkan peningkatan perubahan besar; (8) Solusi Subjek tidak harus secara langsung ditemukan bisa dengan identifikasi masalah yang dilakukan oleh Subjek atau terapis; (9) Keterampilan percakapan yang diperlukan oleh terapis untuk mengundang Subjek untuk membangun solusi berbeda dari yang dibutuhkan untuk mendiagnosis dan mengobati masalah Subjek.

Terapi SFT diberikan kepada anggota keluarga dalam kasus ini dengan alasan bahwa masalah yang dialami sebagai salah satu permasalahan yang muncul yang berdampak pada hubungan pada ibu dan anak. Tujuan dari SFT adalah mengubah pola komunikasi yang terjalin antara ibu dan anak yang selama ini kurang mampu berkembang dengan baik karena kualitas hubungan ibu dan anak bertengkar karena ketidaksepakatan serta pertentangan sehingga dengan SFT akan membentuk pola komunikasi yang lebih baik dan positif serta mencari solusi untuk memecahkannya. Adapun prosedur sesi dari SFT yang digunakan dalam kasus ini dilakukan dalam 6 sesi sebagai berikut.

Sesi pertama: Building Raport.Pada sesi ini terapis membangun rapport dan menumbuhkan kepercayaan pada setiap anggota keluarga dan memberikan gambaran akan terapi yang dilakukan dengan dihadirkannya ibu dan anak secara bersama-sama, kegiatan ini bertujuan untuk memotivasi subjek agar bersedia mengikuti proses terapi hingga akhir sesi.

Pada sesi ini dilakukan selama dua kali karena Subjek D masih belum nyaman dengan praktikan. Setelah pertemuan kedua, Subjek D dengan sudah mulai dekat dengan praktikan dan mengajak praktikan bercerita sambil melihat youtube bersama. Sedangkan ibu W langsung percaya dengan praktikan dan menginginkan solusi terbaik atas masalahnya. Agar anaknya juga dapat terbuka dan menuruti keinginannya.

Sesi Kedua: Penggalian masalah per anggota keluarga. Pada sesi ini terapis menggali permasalahan pada anak D dengan menumbuhkan kepercayaan untuk mengutarakan masalahnya. Pada tahap penggalian masalah ada beberapa teknik yang dilakukan yaitu scalling question, exceptions to the problem, dan presuppositional questioning. Target pada sesi ini adalah D mengungkapkan perasaan dan permasalahan serta keinginannya kedepan. Sesi ini berlangsung selama 2 kali pertemuan untuk membuat D semakin nyaman dan percaya pada praktikan. Scalling question yang D jawab dengan skor 2 dimana ia sangat tidak suka jika dibentak, apalagi dimarahi oleh ibu W. Presuppositional questioning bahwa D sudah merasa lega ketika ia menyahuti ibunya karena menurutnya jika ia diam ibunya akan lebih cerewet dan 
berbicara yang tidak-tidak. Exception to the problem, D merasa bahagia apabila sehari saja dia tidak mendengar ibunya marah-marah padanya, membiarkan ia bermain, membuat slime, dan menonton youtube.

Sesi Ketiga: Penggalian masalah pada ibu. Pada sesi ini terapis menggali permasalahan dari ibu W. Dengan menumbuhkan kepercayaan untuk mendengarkan dari sisi pihak ibu dan respon ibu atas D dan hubungan antara ibu W dan D. Pada tahap penggalian masalah ada beberapa tekhnik yang dilakukan yaitu scaling question, normalization, questioning dan exceptions to the problem. Target pada sesi ini ibu W dapat mengungkapkan segala permasalahan yang terjadi dan bagaimana masalah yang terjadi pada D. Sesi ini berjalan dengan lancer, diawal sesi ibu W menceritakan bagaimana pola asuhnya terhadap D. Dapat disimpulkan bahwa $\mathrm{W}$ mengembangkan pola asuh otoriter yang menurut $\mathrm{W}$, ia harus keras dan mengatur segala sesuatu untuk D agar D menjadi disiplin dan tidak manja serta dapat menuruti segala apa yang diperintahkan oleh W. Scalling questions yang dijawab oleh W yaitu skor 2 dimana ia sangat stress dengan perilaku D. Presuppositional questioning, W menyatakan bahwa selama ini, ia bersikap keras dengan mengatur jadwal D dari bangun tidur, memarahi D itu akan membuat D menjadi anak yang disiplin dan penurut. Exceptions to the problem, W merasa yang membuatnya bahagia ketika D melakukan beberapa perintah yang diperintahkannya, tidak banyak bertanya, dan tidak banyak meminta ini itu, dan juga waktu berkumpul bertiga bersama keluarga tanpa D dan W saling menyahuti perkataan satu-sama lain.

Sesi keempat: Komunikasi problem (seluruh anggota) dan pemberian tugas. Sesi ini berjalan lancar, meskipun diawal D banyak diam dan ibu W yang lebih banyak mengutarakan apa yang dirasakannya selama ini. Praktikan beberapa kali mengulang dan memancing kembali terkait dengan jawaban keduanya di sesi sebelumnya. Mereka saling menyampaikan perasaan masing-masing walaupun diawal D terlihat takut dan ragu untuk menyampaikan apa yang ia rasakan dan ibu W yang mendominasi untuk mengungkapkan perasaannya. Ketika mereka saling mengungkapkan perasaan, keduanya kembali saling menyahuti satu sama lain. Namun, diakhir sesi D memutuskan untuk mengikuti perintah ibunya, akan memperlakukan ibunya seperti D bersikap pada ayahnya, dan mencoba untuk tidak menyahuti ataupun membentak ibu W. Ibu W memutuskan bahwa ia juga akan mencoba untuk berbicara dengan lembut kepada D, tidak akan membentak, apalagi sampai mencubit dan berusaha untuk berbicara dan mencari topik hangat ketika bersama D.

Sesi kelima: Evaluasi perubahan, tugas lanjutan. Pada sesi ini dilakukan evaluasi melihat sejauh mana solusi yang telah dilakukan oleh masing-masing anggota keluarga. Terapis mengevaluasi apakah solusi yang telah ditemukan dapat diterapkan untuk mengubah komunikasi yang terjalin antar anggota keluarga, serta melihat bagaimana kekurangan dan kelebihan masing-masing anggota dalam melaksanakan tugasnya tersebut. Pada sesi ini target terpenuhi, $\mathrm{W}$ dan $\mathrm{D}$ saling menjalankan solusi yang telah disepakati. W tidak membentak $\mathrm{D}$ dan menegurnya dengan pelan, W sudah mulai berusaha bercanda dan mengobrol santai dengan $\mathrm{D}$ walaupun menurut D candaan $\mathrm{W}$ agak sedikit aneh. D mengungkapkan bahwa ia senang karena tidak dibentak oleh ibunya dan menyampaikan perasaan menyesalnya karena pernah dan beberapa kali membentak ibu W.

Sesi keenam: Evaluasi perubahan, the surprise task. Pada sesi ini dilakukan evaluasi kembali apakah solusi yang telah diterapkan dapat diterapkan oleh anggota keluarga dan mengubah keadaan dalam keluarga. Pada sesi ini digali kembali bagaimana kelebihan dan kekurangan masing-masing anggota keluarga dalam menjalankan tugasnya dan memperbaiki komunikasi yang terjalin. Setelah menyampaikan perubahan yang dialami dan saling mengkoreksi setiap anggota keluarga memberikan surprise task pada anggota keluarganya. Pada sesi ini, D mengungkapkan bahwa ia masih merasa aneh dengan sikap ibu W yang mengajaknya bercanda namun D senang karena ibu W sedikit seperti ayah. Ibu W sangat berusaha untuk 
mengontrol agar ia tidak marah ataupun terkesan mencecar D dengan perintah-perintah yang harus dilakukan D. Mereka berdua saling memberikan surprise task dimana D akan menyiapkan seragamnya sendiri di pagi hari, tidak telat ke sekolah, menyapu rumah, membereskan tas dan perlengkapan sekolahnya jika sudah selesai di pakai. Sementara W akan membangunkan D dengan lembut malalui usapan, pelukan, dan mencium D dipagi hari seperti yang dilakukan oleh ayahnya.

Sesi ketujuh: Evaluasi dan terminasi. Pada sesi ini dilakukan evaluasi kembali seperti pada tahap sebelumnya. Sesi ini melihat apakah solusi dapat diterapkan oleh anggota keluarga dan melihat sejauh apa usaha dan kendala pada tugas yang telah disepakati. Diakhir terapis menanyakan perubahan yang terjadi selama proses dalam intervensi dan memberikan scaling question untuk mengidentifikasi perasaan setelah dilakukan terapi. Sesi ditutup dan anggota keluarga didorong untuk tetap melaksanakan tugas-tugasnya tersebut.

Sesi ini berjalan lancar, W dan D mampu konsisten dalam menerapkan solusi atas masalah yang dialami oleh keduanya. D mengatakan bahwa ia sangat merasa senang ketika ibunya membangunkannya dengan usapan, ciuman, dan pelukan bahkan beberapa kali W memuji D karena sudah melakukan tugasnya dengan baik. D mengatakan hal tersebut dengan senyum lebar dan sangat senang. Sementara W sangat bersyukur karena D bisa santai mengobrol dengannya mulai bercerita tentang kejadian yang D alami di sekolah seperti saat D biasanya bercerita dengan ayahnya. Scalling question W 7 dan D 7.

\section{Hasil dan Pembahasan}

\section{Hasil}

Setelah menjalani rangkaian intervensi solution focused therapy, terdapat perubahan berupa komunikasi yang positive antara ibu da anak yang juga membuat interaksi keduanya lebih baik dari sebelumnya. Sebelum terapi dilakukan, $\mathrm{W}$ dan D memiliki interaksi dan komunikasi yang kurang baik, saling berteriak, membentak, saling menyahuti. Perubahan pola komunikasi dapat diamati dengan perilaku yang dimunculkan oleh anggota keluarga dan perilaku tersebut dilakukan pada setiap harinya. Dengan kata lain, ibu W dan anaknya D mampu membentuk sebuah perilaku sebagai solusi untuk menyelesaikan permasalahan yang terjadi dan disepakati secara bersama. Adapun kondisi sebelum dan sesudah intervensi dijelaskan pada Tabel 1

Perubahan yang terjadi antara $\mathrm{W}$ dan $\mathrm{D}$ berdampak pada pola komunikasi antara $\mathrm{W}$ dan $\mathrm{D}$. Mereka saling mengetahui pandangan dan keinginan masing-masing sehingga timbulah solusi untuk memperbaiki dan memahami kebutuhan dan peranan masing-masing. $\mathrm{W}$ menyadari bahwa pola asuh yang dia terapkan secara tidak sadar seperti ia mengulang kembali cerita di masa lalunya dan itu tidak baik terhadap hubungannya dengan anaknya. D menyadari bahwa ketika ia mematuhi perintah ibunya tanpa harus diberi tahu terlebih dahulu membuat ibunya tidak marah dan bisa membuat ibu W bercanda seperti ayahnya memperlakukannya.

Setelah 1 minggu dilakukannya intervensi hasil follow up menunjukkan ibu dan anak mampu mempertahankan hasil intervensi yang telah disepakati. ibu selalu menanyakan kegiatan anaknya di sekolah, menyediakan waktu untuk bercanda dengan anak di sore hari ketika selesai bekerja. Ibu juga memuji anak ketika berperilaku baik. Anak juga mampu mempertahankan perilakunya untuk menyiapkan kebutuhannya sendiri dan tanpa diperintah oleh ibunya.

\section{Pembahasan}

Berdasarkan hasil dari solution focused therapy yang dilakukan pada ibu W dan anak D menunjukkan perubahan komunikasi yang positif. Perubahan positif yang dicapai pada pola komunikasi berfokus pada solusi yang dilakukan untuk menyelesaikan permasalahan dengan membuat tugas-tugas pada masing masing anggota (Ratner et al., 2012). Beberapa tugas-tugas 
Tabel 1. Hasil Intervensi SFT

\begin{tabular}{ll}
\hline Kondisi Sebelum Intervensi & Kondisi Sesudah Intervensi \\
\hline D dan W yang selalu bertengkar karena D & D dan W berbicara secara baik-baik \\
tidak bisa mengurus dirinya sendiri & tanpa harus saling membentak. D \\
& sudah mulai untuk menyiapkan \\
& keperluan sekolahnya sendiri \\
W tidak pernah mengajak D bercanda & W mulai mengajak D berbicara santai \\
dan D yang mengabaikan keberadaan & dan bercanda walaupun agak kaku \\
ibunya jika bersama ayahnya & diawal namun keduanya bisa berbicara \\
& santai dan D bercerita tentang hal yang \\
& dialaminya di sekolah. \\
D jarang melakukan tugas rumah yang & D menyapu, membersihkan bekas \\
diperintahkan oleh ibu W & mainan slime, menaruh tas \\
& ditempatnya, dan membereskan \\
buku-bukunya ketika selesai dibelajar. \\
Ibu W tidak pernah memuji, mencium, & Setiap pagi, ibu W membangunkan D \\
ataupun mengelus rambut D & dengan mengelus rambut, dan mencium \\
& D sehingga membuat D merasa sangat \\
& senang. \\
\hline
\end{tabular}

yang disepakati oleh ibu $\mathrm{W}$ dan $\mathrm{D}$ dijalankan dengan cukup baik. Ibu $\mathrm{W}$ dan $\mathrm{D}$ menyadari bahwa mereka memiliki perbedaan pandangan dan adanya keinginan yang berbeda yang tidak tersampaikan dengan cara yang baik sehingga memperburuk pola komunikasi yang terjalin antara keduanya.

Dengan mengikuti seluruh sesi dalam terapi SFT, ibu W dan anak D mengembangkan solusi untuk memperbaiki komunikasi mereka agar lebih baik lagi serta membuat kualitas hubungan mereka berjalan dengan baik pula. Zarnaghash et al., (2013) menyatakan bahwa pola komunikasi yang baik dalam keluarga memiliki dampak yang baik pada kesehatan mental anggota keluarga dimana dimensi percakapan menjadi predictor yang baik untuk kesehatan mental anak. Hal ini juga membuktikan bahwa pada dasarnya SFT berfokus pada solusi didasarkan pada asumsi untuk mengubah persepsi Subjek mengenai masalah mereka dan membuat mereja menemukan solusi serta perubahan melalui berbicara dengan Subjek tentang bagaimana solusi dalam menyelesaikan masalah yang mereka hadapi (Shirashiani \& Namani, 2017).

Solusi yang dicapai oleh keluarga ini adalah ibu yang akan mengajak anak berbicara santai, bercanda, dan tidak akan marah-marah lagi dengan anak. Ibu juga memuji, memeluk, dan mencium anaknya setiap pagi. D juga memutuskan untuk bercerita tentang kegiatan kesehariannya di sekolah dan mulai untuk menyiapkan kebutuhannya sendiri dan mengikuti apa yang diperintahkan oleh ibu W tanpa mencoba untuk membantah. Hal tersebut disepakati oleh keduanya untuk memperbaiki pola komunikasi dan kualitas hubungan mereka berdua. Trepper, (2012) menyatakan bahwa SFT berfokus secara eksklusif pada kekuatan Subjek, ketahanan, dan solusi yang dirancang untuk bersama-sama membangun tujuan harapan terbaik dan mendorong keluarga untuk membuat perubahan kecil menuju tujuan tersebut.

\section{Simpulan}

Solution focused therapy mampu memperbaiki pola komunikasi pada ibu dan anak. Hal ini terlihat pada bagaimana ibu dan anak menemukan solusi dari masalah yang hadapinya. Pandangan yang saling berbeda dan saling mengetahui keinginan masing-masing memunculkan solusi yang telah mereka temukan sendiri. Solusi yang ditemukan mampu diterapkan dalam 
kehidupan sehari-hari sehingga ibu dana anak mampu melakukan perubahan pola komunikasi yang lebih baik dan adanya kesempatan untuk saling memperbaiki kualitas keduanya untuk berinteraksi.

\section{Referensi}

Bibi, F., Chaudhry, A. G., Awan, E. A., \& Tariq, B. (2013). Contribution of parenting style in life domain of children. Journal Of Humanities And Social Science, 12(2), 91-95.

Carr, A. (2006). Family therapy current opinion in psychiatry (Second Edi, Vol. 9). John Wiley \& Sons Ltd. https://doi.org/http://dx.doi.org/10.1097/00001504-199605000-00006

Fitzpatrick, M. A. (2004). Journal of family communication patterns theory: Observations on tts development and application. Journal of Family Communication, 4(3-4), 167-179.

Kumar, P., \& Tiwari, S. C. (2008). Family and psychopathology: an overview series-1: children and adults. Delhi Psychiatry Journal, 11(2), 140-149.

Lutz, A. B. (2014). Learning solution-focused therapy an illustrated guide (First edit). Washington, DC: American Psychiatric Publishing.

Muraru, A. A., \& Turliuc, M. N. (2012). Family-of-origin, romantic attachment, and marital adjustment: a path analysis model. Procedia - Social and Behavioral Sciences, 33, 90-94. https://doi.org/10.1016/j.sbspro.2012.01.089

Nelson, J. A., O’Brien, M., Grimm, K. J., \& Leerkes, E. M. (2014). Identifying mother-child interaction styles using a person-centered approach. Social Development, 23(2), 306-324. https://doi.org/10.1111/sode.12040

Ratner, H., George, E., \& Iveson, C. (2012). Solution focused brief therapy 100 key points and techniques. London: Routledge/Taylor and Francis Group.

Senthil, M. (2016). Impact of family dysfunctions on child and adolescents mental health. The International Journal of Indian Psychology, 4(76). Retrieved from http://www.ijip.in

Shahraki-sanavi, F., Baghbanian, A., \& Ansari-moghaddam, A. (2013). A study on family communication pattern and parenting styles with quality of life in adolescent. Journal of the Pakistan Medical Association, 63(11), 1393-1398.

Shirashiani, A., \& Namani, E. (2017). Effectiveness of the combination of solution-focused terapy and narrative therapy in marital adjustment among incompatible Iranian women. Journal of Psychiatry, 7, 79-89. https://doi.org/10.4236/ojpsych.2017.72008

Sunarty, K., \& Dirawan, G. D. (2015). Development parenting model to increase the independence of children. International Education Studies, 8(10), 107-113. https://doi.org/10.5539/ies.v8n10p107

Trepper, T. S. (2012). Solution-focused brief therapy with families. Asia Pacific Journal of Counselling and Psychotherapy, 3(2), 137-148. https://doi.org/10.1080/21507686.2012.718285

Y, S. T. (2017). Construction andvalidation of PS-FFQ (Parenting style four factor questionnaire). International Journal of Engineering Development and Research, 5(3), 426-437.

Zarnaghash, M. (2011). Social and the relationship between the desired disciplinary behavior and family functioning locus of control and self esteem among high school students in cities of Tehran province. Procedia - Social and Behavioral Sciences, 30, 2463-2467. https://doi.org/10.1016/j.sbspro.2011.10.481

Zarnaghash, M., Zarnaghash, M., \& Zarnaghash, N. (2013). The relationship between family communication patterns and mental health. Procedia - Social and Behavioral Sciences, 84, 405-410. https://doi.org/10.1016/j.sbspro.2013.06.575 